\title{
New core promoter element in RNA polymerase II-dependent transcription: sequence-specific DNA binding by transcription factor IIB
}

\author{
Thiery Lagrange, ${ }^{1}$ Achillefs N. Kapanidis, ${ }^{2}$ Hong Tang, ${ }^{2}$ Danny Reinberg, ${ }^{1}$ and Richard H. Ebright ${ }^{2,3}$ \\ ${ }^{1}$ Howard Hughes Medical Institute and Department of Biochemistry, University of Medicine and Dentistry of $\mathrm{N}$ ew \\ Jersey-Robert Wood Johnson M edical School, Piscataway, N ew Jersey 08854; ${ }^{2}$ Department of Chemistry and Waksman \\ Institute, Rutgers University, N ew Brunswick, N ew Jersey 08855 USA
}

\begin{abstract}
A sequence element located immediately upstream of the TATA element, and having the consensus sequence 5'-G/C-G/C-G / A-C-G-C-C-3', affects the ability of transcription factor IIB to enter transcription complexes and support transcription initiation. The sequence element is recognized directly by the transcription factor IIB. Recognition involves $\alpha$-helices $4^{\prime}$ and $5^{\prime}$ of IIB, which comprise a helix-tum-helix DNA-binding motif. These observations establish that transcription initiation involves a fourth core promoter element, the IIB recognition element (BRE), in addition to the TATA element, the initiator element, and the downstream promoter element, and involves a second sequence-specific general transcription factor, IIB, in addition to transcription factor IID.
\end{abstract}

[Key Words: IIB recognition element; TATA element; transcription factor IIB; helix-turn-helix; DNA binding]

Received September 17, 1997; revised version accepted October 30, 1997.

Efficient transcription initiation at a human protein-encoding gene requires assembly on promoter DNA of a multiprotein complex containing RNA polymerase II (Pol II) and six general transcription factors, IIA, IIB, IID, IIE, IIF, and IIH (for review, see Orphanides et al. 1996; Roeder 1996; Nikolov and Burley 1997). Previous work establishes that assembly of the complex involves three core promoter elements: (1) the TATA element, located near position -30 , (2) the initiator element, located near position -1 , and (3) the downstream promoter el ement, located near position +30 (Burke and Kadonaga 1996; Orphanides et al. 1996; Roeder 1996). Transcription factor IID is responsible for recognition of at least two of these elements. One subunit of IID, TATA-binding protein (TBP), is responsible for recognition of the TATA element; one or more of the remaining subunits of IID, TBP-associated factors (TAFs), is responsible for recognition of the downstream promoter el ement. It is not clear which factor is responsible for recognition of the initiator el ement.

The crystal lographic structure of a ternary complex of transcription factor IIB core domain (IIBC), TBP core domain (TBPC), and a 16-bp DN A fragment containing the TATA element shows that IIBC interacts with both TBPC and DNA, interacting with the DNA major groove immediately upstream of the TATA element and the DN A minor groove immediately downstream of the TATA element (Fig. 1; Nikolov et al. 1995). In the crystallo-

${ }^{3}$ Corresponding author.

E-MAIL ebright@mbc1.rutgers.edu; FAX (732) 445-5735. graphic structure, details of the interaction between IIBC and the DNA major groove upstream of the TATA element are incomplete, since the structure was determined using a DNA fragment containing only three nucleotide pairs upstream of the TATA el ement ( $\mathrm{N}$ ikolov et al. 1995). However, DNA-binding and site-specific protein-DNA photocross-linking experiments confirm that interaction between IIB and the DN A major groove upstream of the TATA el ement occurs and indicate that the interaction is extensive, spanning up to 7-9 nucleotide pairs (Lee and Hahn 1995; Lagrange et al. 1996). The observation that IIB makes extensive interactions with the DNA major groove upstream of the TATA element raises the possibility that the ability of IIB to enter into transcription complexes and, thus, the ability of IIB to support transcription initiation, may be affected by the DNA sequence upstream of the TATA element ( $\mathrm{La}$ grange et al. 1996).

In this study, we show that the seven nucleotide pairs immediately upstream of the TATA element constitute a new core promoter element, and we show that IIB directly recognizes this element.

\section{Results}

New core promoter el ement in Pol II-dependent transcription initiation

As a first step in testing the possibility that the ability of IIB to enter into transcription complexes may be affected 


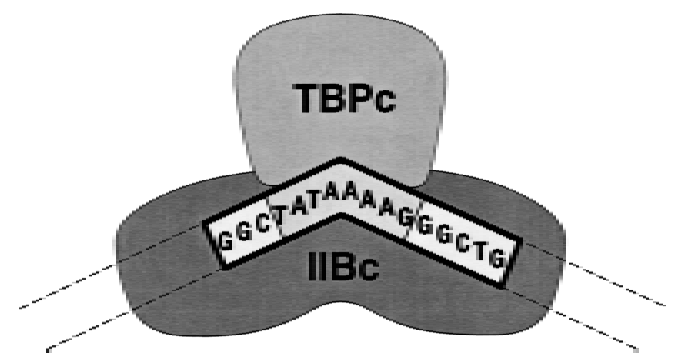

Figure 1. Structure of the IIB-TBP-TATA complex. Schematic representation of the crystallographic structure of a ternary complex of transcription factor IIB core domain (IIBC), TBP core domain (TBPC), and a 16-bp DNA fragment containing the TATA element (Nikolov et al. 1995). (TATAAAAG) TATA element; (GGC and GGCTG) DNA segments upstream and downstream of the TATA element in the 16-bp DN A fragment; (dashed lines) projected paths of distal upstream and downstream DN A segments.

by the DNA sequence immediately upstream of the TATA element, we performed binding-site selection (Oliphant et al. 1989; Blackwell and Weintraub 1990; Blackwell et al. 1990; Mavrothalassitis et al. 1990; Thiesen and Bach 1990). We constructed a library of DNA fragments having the TATA el ement of the adenovirus major late promoter preceded by 12 randomized nucleotide pairs (1.7 $\times 10^{7}$ DNA fragments), formed IIB-TBPDNA complexes using saturating TBP and limiting IIB, isolated IIB-TBP-DNA complexes by nondenaturing PAGE, and amplified DNA fragments in complexes by PCR. After four cycles of selection and amplification, electrophoretic mobility shift experiments indicated that the pooled selected DNA fragments exhibited an apparent fivefold higher affinity for IIB in IIB-TBPCDNA complex formation than the unselected randomized DNA fragments, indicating that the procedure in fact had selected DN A fragments having above-average affi nities for IIB (data not shown). Sequences of 19 cloned sel ected DNA fragments revealed a statistically significant $(P<0.002)$ preference for $G$ three nucleotides upstream of the TATA element (Fig. 2A). The wild-type adenovirus major late promoter-a standard test promoter for analysis of Pol II-dependent transcription, chosen for its exceptional strength (Corden et al. 1980)contains $\mathrm{G}$ at this position (i.e., position -34) (Fig. 2A, left). We suggest that $G$ at this position is part of a sequence element correlated with high affinity for IIB in IIB-TBP-DNA complex formation.

To define further the putative sequence el ement, we performed a second round of binding site selection ("round-2"), in this round, using a library of DNA fragments having the TATA element of the adenovirus major late promoter preceded by the sequence $5^{\prime}-\mathrm{N}_{5} \mathrm{GN}_{2}-3^{\prime}$, in which the nucleotides corresponding to positions -39 to -35 and -33 to -32 were randomized and the nucleotide corresponding to position -34 was constrained as $G$ $\left(1.6 \times 10^{4}\right.$ DNA fragments). After seven cycles of selection and amplification, sequences of the pool ed round-2sel ected DNA fragments reveal ed strong nucleotide preferences at the seventh, sixth, fifth, fourth, second, and first positions upstream of the TATA element (Fig. 2B, bottom). Sequences of 22 cloned round-2-selected DN A fragments confirmed strong, statistically significant, nucleotide preferences at these positions (Fig. 2B, right).
A

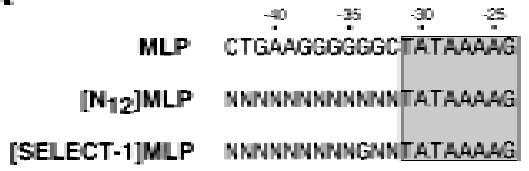

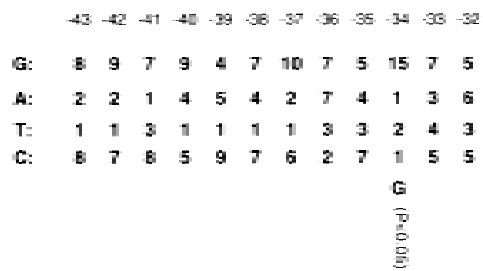

B
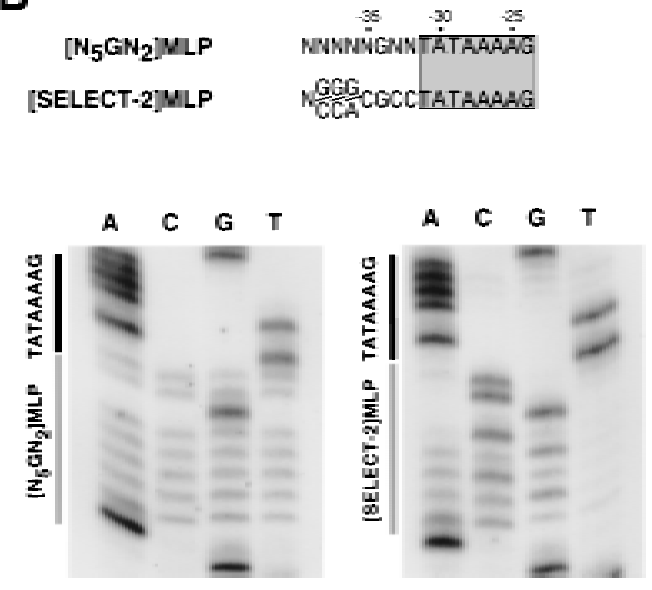

Figure 2. New sequence element. (A) Binding site sel ection, round 1. (Left) Positions -43 to -24 of the wild-type, $\mathrm{N}_{12}$-randomized, and consensus round-1-selected adenovirus major late promoter sequences (TATA element boxed and shaded). (Right) Summary of 19 round-1-selected sequences. (B) Binding site selection, round 2. (Left) Positions -39 to -24 of the $\mathrm{N}_{5} \mathrm{GN}_{2}$ - randomized and consensus round2-sel ected adenovirus major late promoter sequences (TATA element boxed and shaded). (Right) Summary of 22 round-2selected sequences. (Bottom) Sequences of pooled $\mathrm{N}_{5} \mathrm{GN}_{2}$-randomized and round-2selected DNA fragments. Probabilities in $A$ and $B$ are from $\chi^{2}$ analysis (Statistix $v$. 2.1). 
T aken together, the results of the first and second rounds of binding site selection yield the consensus sequence 5'-G/C-G/C-G/A-C-G-C-C-3' (Fig. 2B, left).

Results of el ectrophoretic mobility shift DNA-binding experiments indicate that the pooled round-2-selected DNA fragments exhibit an apparent affinity for IIB in IIB-TBP-DN A complex formation that is $\sim 30$-fold higher than that of unselected $\mathrm{N}_{8}$-randomized DN A fragments, $\sim 8$-fold higher than that of unselected $\mathrm{N}_{5} \mathrm{GN}_{2}$-randomized DNA fragments, and slightly higher than that of the wild-type adenovirus major late promoter (Fig. 3A). The electrophoretic mobility shift results confirm that the identity of the nucleotide corresponding to position -34 of the adenovirus major late promoter affects affinity for IIB (Fig. 3A, panel 1 vs. panel 2), confirm that the identities of the nucleotides corresponding to positions -39 to -35 and -33 to -32 of the adenovirus major late promoter affect affinity for IIB (Fig. 3A, panel 2 vs. panel 3), and indicate that the wild-type adenovirus major late promoter, which contains a 5-of-7 match to the consensus sequence (Fig. 2), has high, but not optimal, affinity for IIB (Fig. 3A, panel 3 vs. panel 4).

To confirm the electrophoretic mobility shift DNAbinding results in a true equilibrium assay - an assay not requiring separation of bound and free components-we performed fluorescence anisotropy DN A-binding experiments (for review, see Heyduk et al. 1996; Lundblad et al. 1996). Fluorescence anisotropy DNA-binding experiments are based on the fact that successive additions of proteins $\mathrm{P}_{1}$ and $\mathrm{P}_{2}$ to a fluorochrome-labeled DNA fragment normally result in successive decreases in molecular rotation of the DNA fragment, and therefore normally result in successive increases in fluorescence anisotropy. We started with preformed binary complexes of TBPC and a fluorochromelabeled DNA fragment
(Heyduk et al. 1996), titrated with increasing concentrations of IIB, and quantified IIB-TBPC-DN A complex formation by measurement of increases in fluorescence anisotropy. We constructed and analyzed four fluorochrome-labeled DNA fragments: one DNA fragment containing the consensus round-2-selected sequence, 5'-GGGCGCC-3', and three DN A fragments containing the wild-type, $-34 \mathrm{~A}$, and $-37 \mathrm{~A} ;-34 \mathrm{~A}$ adenovirus major late promoter sequences (Fig. 3B, left). The results establish that the consensus round-2-selected sequence has an affinity for IIB in IIB-TBPC-DNA complex formation threefold higher than that of the wild-type adenovirus major late promoter $\left(\mathrm{K}_{\mathrm{B}}=2.2 \pm 0.1 \times 10^{7} / \mathrm{M}\right.$ vs. $\mathrm{K}_{\mathrm{B}}=7.0 \pm$ $1 \times 10^{6} / \mathrm{M}$; Fig. 3B). The results further establish that the $-34 \mathrm{~A}$ single substitution and the $-37 \mathrm{~A} ;-34 \mathrm{~A}$ double substitution result in six- to sevenfold defects in affinity $\left(K_{B}=9.5 \pm 1 \times 10^{5} / \mathrm{M}\right.$ and $1.1 \pm 0.1 \times 10^{6} / \mathrm{m}$; Fig. 3B $)$. We conclude that the identities of the seven nucleotides immediately upstream of the TATA element affect affinity for IIB in IIB-TBP-DNA complex formation, and that G at the position corresponding to position -34 of the adenovirus major late promoter is an especially critical determinant.

To determine whether the sequence element functions in transcription, we performed abortive initiation in vitro transcription experiments with adenovirus major late promoter derivatives containing the round-2-selected, $\mathrm{N}_{8}$-randomized, $\mathrm{N}_{5} \mathrm{GN}_{2}$-randomized, and wildtype sequences, using fixed concentrations of promoter DN A, TBP, IIE, IIF, IIH, and Pol II, and variable concentrations of IIB. The results establish that the IIB concentration dependence for transcription initiation at the promoter containing the round-2-selected sequence is about one-eighth that of the promoter containing the $\mathrm{N}_{8}$-randomized sequence (Fig. 4A, panels 1 and 3), about
Figure 3. N ew sequence el ement is important for TBP-IIB-DNA complex formation. (A) Electrophoretic mobility shift analysis of IIB-TBP-DNA complex formation. Experiments were performed with DNA fragments containing $\mathrm{N}_{8}$-randomized, $\mathrm{N}_{5} \mathrm{GN}_{2}$-randomized, pooled round-2-sel ected, and wild-type adenovirus major late promoter sequences. TBP was at $30 \mathrm{~nm}$; IIB was at $0,0.0625,0.25$, 1,4 , and $16 \mathrm{~nm}$. The upper and lower bands correspond to the IIB-TBP-DNA complex and free DN A, respectively; under the conditions used, the TBP-DNA complex is not stable to electrophoresis (see Maldonado et al. 1990). (B) Fluorescence anisotropy analysis of IIB-TBPCDNA complex formation. (Left) DNA fragments used. The DNA fragments contain fluorescein and wild-type, $-34 \mathrm{~A}$, $-37 \mathrm{~A} ;-34 \mathrm{~A}$, and consensus round-2-selected adenovirus major late promoter sequences. Fluorescein is indicated as " $F$ "; positions -37 and -34 are boxed; the TATA el ement is boxed and shaded. (Right) Data. (๑) DN A fragment M LP-F; (O) DN A fragment [-34A ]M LP-F; ( $\square$ ) DN A fragment [-37A;-34A ]M LP-F; $(\diamond)$ DNA fragment [SELECT-2CON S]M LP-F.

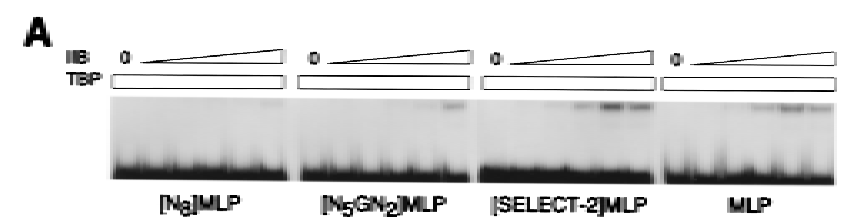

B
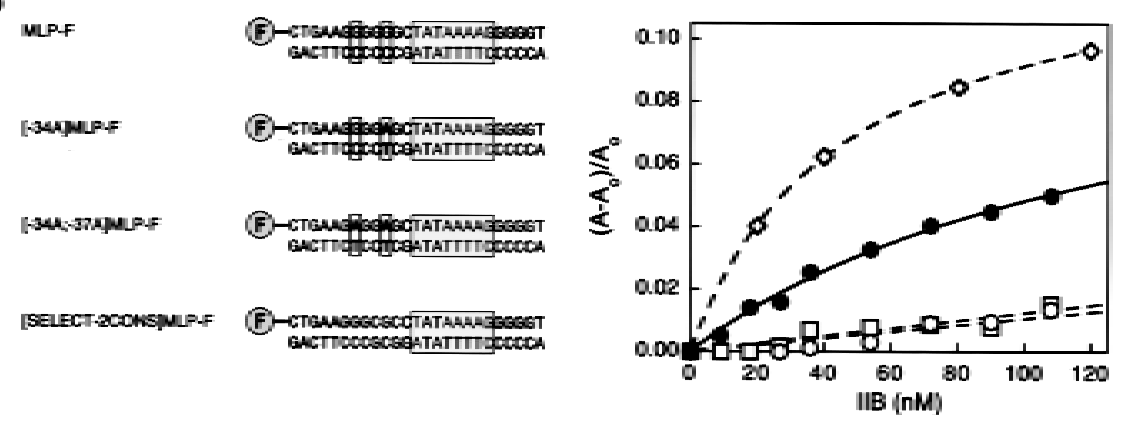
one-quarter that of the promoter contai ning the $\mathrm{N}_{5} \mathrm{GN}_{2}$ randomized sequence (Fig. 4A, panels 2 and 3), and slightly less than that of the wild-type adenovirus major late promoter (Fig. 4A, panels 3 and 4; see especial ly data for lower IIB concentrations). At each tested IIB concentration, the promoter containing the round-2-sel ected sequence is substantially more proficient in transcription initiation than the promoters containing the $\mathrm{N}_{8}$-randomized and $\mathrm{N}_{5} \mathrm{GN}_{2}$-randomized sequences, and, at four of five tested IIB concentrations, the promoter containing the round-2-sel ected sequences is more proficient in transcription initiation than the wild-type adenovirus

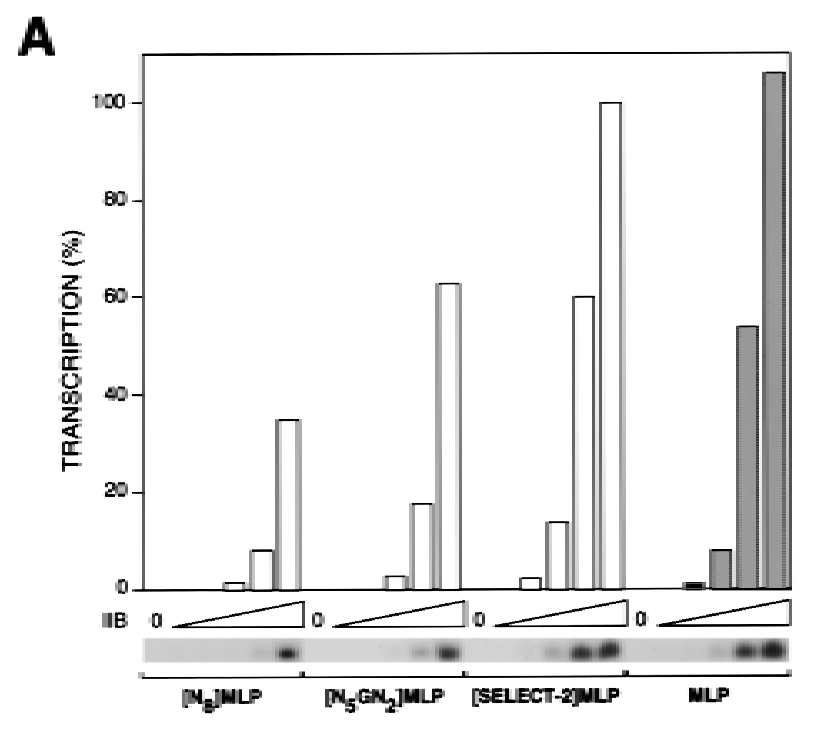

B

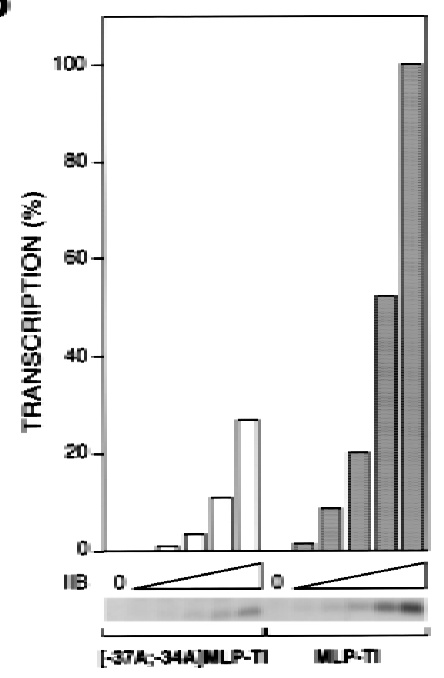

Figure4. N ew sequence el ement is important for transcription initiation. (A) Transcription initiation at the $\mathrm{N}_{8}$-randomized, $\mathrm{N}_{5} \mathrm{GN}_{2}$-randomized, pooled round-2-selected, and wild-type adenovirus major late promoters. IIB was at $0,15,60,240,960$, and 3800 pм. (B) Transcription initiation at $-37 A ;-34 A$ and wildtype adenovirus major late promoter derivatives. IIB was at 0 , $20,40,80,160$, and 320 pм. major late promoter (Fig. 4A). Results of analogous experiments with adenovirus major late promoter derivatives contai ning the wild-type and $-37 \mathrm{~A}$; $-34 \mathrm{~A}$ sequences indicate that the IIB concentration dependence for transcription initiation at the promoter containing the wildtype sequence is about one-third that of at the promoter containing the $-37 \mathrm{~A}$; $-34 \mathrm{~A}$ double substitution (Fig. 4B).

We conclude that the seven nucleoti de pairs upstream of the TATA element constitute a bona fide core promoter element-i.e., a sequence element affecting basal preinitiation complex assembly and basal transcription initiation.

\section{IIB recognizes the new core promoter element}

The simplest interpretation of the results in Figures 2 to 4 is that IIB recognizes the new promoter element directly. However, because the experiments in Figures 2 to 4 were performed in the presence of TBP, and because IIB interacts with TBP ( $\mathrm{Nikolov}$ et al. 1995; Tang et al. 1996), an alternative possible interpretation is that IIB recognizes the element indirectly (e.g., recognizing an element-dependent TBP conformation).

To determine whether IIB recognizes the new promoter element directly, we performed fluorescence anisotropy DN A-binding experiments (Heyduk et al. 1996; Lundblad et al . 1996) investigating whether IIB is able to bind to DNA in the absence of TBP and, if so, whether binding is affected by the element. The results in Figure 5A establish that IIB interacts with a fluorochrome-labeled DNA fragment containing the wild-type adenovirus major late promoter sequence to form a IIB-DNA complex with an equilibrium binding constant of $2.3 \pm 1 \times 10^{7} / \mathrm{m}$. The interaction is sequence specific; thus, the interaction is observable in the presence of a 400-fold mass excess of competitor DNA (see Materials and $M$ ethods). The interaction requires the new promoter element; thus, affinity is reduced $\sim 7$-fold by the $-34 \mathrm{~A}$ substitution within the adenovirus major late promoter sequence and $\sim 20$-fold by the $-37 \mathrm{~A}$;-34A double substitution within the adenovirus major late promoter sequence $\left(K_{B}=3.4 \pm 0.3 \times 10^{6} / \mathrm{M}\right.$ and $1.3 \pm 0.4 \times 10^{6} / \mathrm{M}$; Fig. 5A). Essentially identical results are obtained using IIB (Fig. 5A) and IIBC (Fig. 5B), indicating that the determinants of IIB for the interaction are contained within IIBC. We conclude that IIB is a sequence-specific DNAbinding protein and is directly responsible for recognition of the new promoter element.

To confirm the ability of IIB to form IIB-DNA complexes, and to define the position of IIB relative to DNA in IIB-DN A complexes, we performed site-specific protein-DN A photo-cross-linking (Lagrange et al. 1996). We constructed a set of 11 site specifically derivatized adenovirus major late promoter DNA fragments, each having a phenyl-azide photoactivatible cross-linking agent and an adjacent radiolabel incorporated at a single, de fined DN A phosphate (template strand phosphates -45 , $-43,-41,-39,-37,-35$, and -33 upstream of the TATA element, and template strand phosphates $-24,-22,-20$, 
A

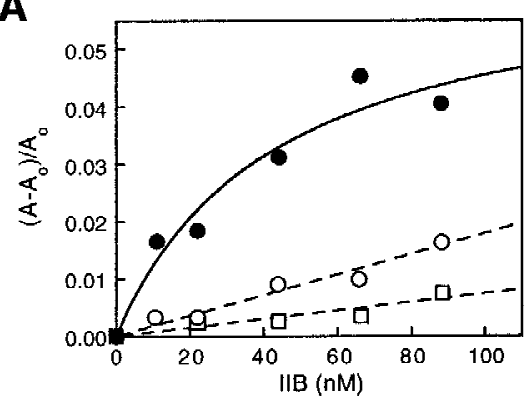

B

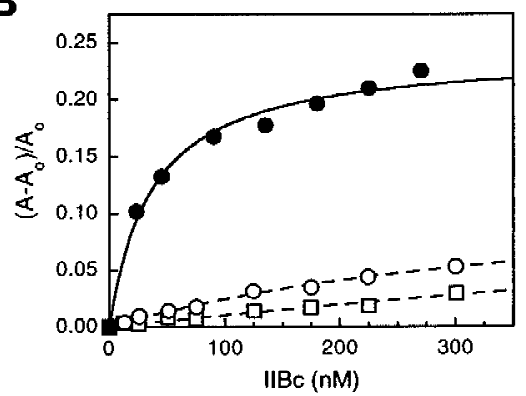

Figure 5. IIB recognizes the new sequence element. (A) Fluorescence anisotropy analysis of IIB-DNA complex formation. (0) DNA fragment MLP-F; $(O)$ DNA fragment [-34A ]M LP-F; ( $\square$ ) DNA fragment [-37A; $-34 \mathrm{~A}] \mathrm{M}$ LP-F (sequences in Fig. 3B). (B) Fluorescence anisotropy analysis of IIBC-DNA complex formation (symbols as in A). (C) Site-specific protein-DNA photo-crosslinking analysis of IIB-TBP-DNA complex formation (top) and IIB-DNA complex formation (bottom). The TATA element is boxed and shaded. (0) Phosphates at which a phenyl-azide photoactivatible cross-linking agent was incorporated; $(+, \pm$ ) sites at which strong and weak cross-linking, respectively, were observed. The autoradiographs present results of reactions with UV irradiation and control reactions without UV irradiation.
C
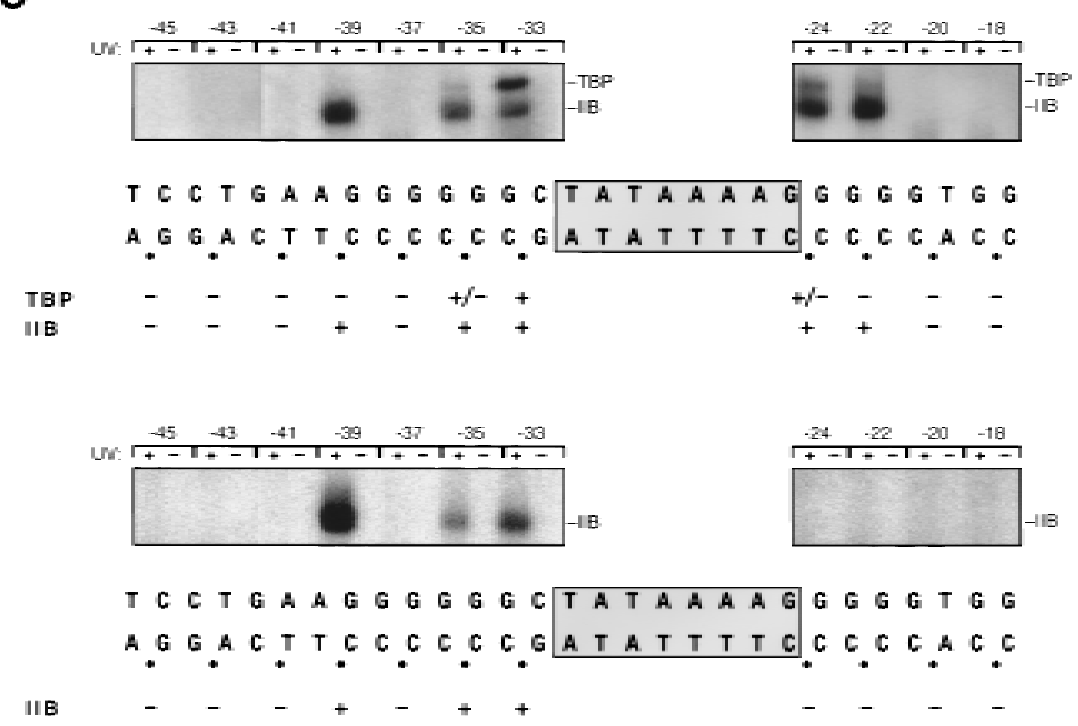

and -18 downstream of the TATA element; Fig. 5C). For each resulting DN A fragment, we equilibrated the DN A fragment with IIB and TBP or with IIB al one, UV-irradiated the reaction mixtures to initiate DNA $\rightarrow$ protein cross-linking, carried out nuclease digestion to el iminate uncross-linked DNA and to convert cross-linked DN A to a cross-linked, radiolabeled 3-5 nucleotide "tag," and identified the "tagged" proteins.

Upstream of the TATA element-in the region corresponding to the new promoter element-the patterns of DNA $\rightarrow$ IIB cross-linking were identical in the reactions containing IIB and TBP (Fig. 5C, top) and the reactions containing IIB alone (Fig. 5C, bottom). In each case, DN A $\rightarrow$ IIB cross-linking occurred at templ ate strand positions $-39,-35$, and -33 . We conclude, in agreement with the conclusions from the fluorescence anisotropy DNA-binding experiments, that IIB is able to form IIBDNA complexes, and we infer that IIB makes similar or identical interactions with DNA upstream of the TATA element in IIB-TBP-DNA and IIB-DN A complexes.

In contrast, downstream of the TATA element, DN A $\rightarrow$ IIB cross-linking occurred only in reactions containing both IIB and TBP (Fig. 5C). We infer that IIB does not, or does not strongly, interact with DNA immediately downstream of the TATA element in IIB-DNA complexes. We speculate that the difference in down- stream interactions in IIB-TBP-DN A and IIB-DN A complexes is a consequence of the presence of the $\sim 80^{\circ} \mathrm{TBP}$ induced DNA bend in the IIB-TBP-DNA complex (J. Kim et al. 1993; Y. Kim et al. 1993; Nikolov et al. 1995; see Fig. 1). The TBP-induced DNA bend in the IIB-TBPDNA complex places the upstream and downstream DNA segments in proper spatial register for simultaneous IIB-DNA interactions with both DNA segments (Nikolov et al. 1995; see Fig. 1). The absence of a corresponding DN A bend in the IIB-DNA complex would preclude simultaneous IIB-DNA interactions with both DNA segments.

IIB recognizes the new core promoter element through a canonical helix-turn-helix motif

As a first step to define the structural basis for recognition of the new promoter el ement, we inspected the crystallographic structure of the IIBC-TBPC-TATA complex in the vicinity of the nucleotides corresponding to positions -34 to -32 of the adenovirus major late promoter and in the projected vicinity of the nucleotides corresponding to positions -38 to -35 of the adenovirus major late promoter (Figs. 1 and $6 \mathrm{E}$ ). Inspection indicated that the interaction between IIB and the DN A major groove 
immediately upstream of the TATA element exhibits unambiguous, but previously unrecognized, structural similarity to the interaction between a helix-turn-helix (HTH) DNA-binding protein and DNA (for review of HTH, see Pabo and Sauer 1992) (Figs. 1 and 6). The amino acid sequence of helices $4^{\prime}$ and $5^{\prime}$ of IIBC matches the sequence profile for HTHs with a Dodd and Egan (1990) score of $4.6 \mathrm{SD}$ (Fig. 6A), and the backbone atoms of helices $4^{\prime}$ and $5^{\prime}$ of IIBC superimpose on the backbone atoms of the HTHs of CAP, $\lambda$ repressor, and Trp repressor with root-mean-square differences of $0.8,0.8$, and 0.9 $\AA$, respectively (Fig. $6 \mathrm{~B}, \mathrm{C}$ ). The orientation of helices $4^{\prime}$ and $5^{\prime}$ of IIBC relative to DNA (modeling DN A upstream of the TATA el ement as B-DN A) falls within the range of orientations observed with canonical HTHs and, in particular, is similar to the orientations observed with the HTHs of $\lambda$ repressor and Trp repressor (Fig. 6B,C).

The structural similarity of IIBC-DNA interaction to Trp repressor-DNA interaction is especially striking. Three consecutive helices of IIBC (helices 3'-5') and Trp repressor (helices $C-E$ ) can be superimposed with a rootmean-square difference of $1.6 \AA$, and the bound DNA segments simultaneously can be superimposed (Fig. 6D).

To test the functional significance of these structural similarities, we have constructed alanine substitutions at the amino acids of IIB corresponding to the amino acids that in HTH DNA-binding proteins make specificity-determining contacts with DN A base pairs (i.e., Asp282, Val-283, Arg-286, and GIn-287 of IIBC) (Figs. 6A and $7 A$ ), and we have assessed the effects on specificity at position -34 of the adenovirus major late promoter (Fig. 7B). We find that the Val-283 $\rightarrow$ Ala and Arg-286 $\rightarrow$ Ala substitutions eliminate specificity at position -34; thus, whereas wild-type IIB exhibits a fivefold preference for $G: C$ versus $A: T$ at position -34 (Figs. 2, 3, and 7B), the substituted IIB derivatives exhibit no preference for $\mathrm{G}: \mathrm{C}$-or even a small preference for A:T (Fig. 7B). In addition, the Val-283 $\rightarrow$ Ala and Arg-286 $\rightarrow$ Ala substitutions result in two- to threefold decreased affinity for IIB-DN A complex formation with the wild-type adenovirus major late promoter sequence (data not shown) and two- to threefold decreased effectiveness in supporting transcription initiation at the wild-type adenovirus major late promoter (Fig. 7C). The Val-283 $\rightarrow$ Ala and Arg$286 \rightarrow$ Ala substitutions exhibit the two defining characteristics of substitutions that permit identification of amino acids that make specificity-determining contacts with DNA base pairs: (1) elimination of specificity between consensus and nonconsensus base pairs at one position within the DNA site, and (2) reduction in affinity for the consensus DN A site ("Ioss-of-contact" substitutions; for review, see Ebright 1991). We conclude that Val-283 and Arg-286 of IIB functionally determine specificity for $G: C$ versus $A: T$ at position -34 , and we propose that Val-283 and Arg-286 make direct contact with G:C at position -34 .

Details of the proposed interactions by $\mathrm{Val}-283$ and Arg-286 of IIB must await determination of a crystallographic structure of a IIB-TBP-TATA complex with a DNA fragment sufficiently long, and having the correct sequence, to encompass the proposed interactions. However, model building suggests that $\mathrm{Val}-283$ may be positioned to make van der Waals interactions with the cytosine $\mathrm{C} 5$ atom of $\mathrm{G}: \mathrm{C}$ at position -34 and that Arg-286 may be positioned to interact with the guanine $O^{6}$ and $\mathrm{N} 7$ atoms of $\mathrm{G}: \mathrm{C}$ at position -34 and/or with the DN Aphosphate backbone at position -34 .

\section{Discussion}

Our results establish the existence of a fourth core promoter element, the "IIB recognition element" (BRE), in addition to the TATA element, the initiator element, and the downstream promoter element, and a second sequence-specific general transcription factor, IIB, in addition to IID. Our results further establish that the degree of similarity between a promoter BRE and the consensus BRE determines the IIB concentration dependences for preinitiation complex assembly and transcription initiation at the promoter-at least in vitro. Determination of whether similarity between a promoter BRE and the consensus BRE has similar effects in vivo awaits further analysis. N everthel ess, on the basis of our results, it is possible that IIB-BRE interaction will play a role in determining the overall strength of a promoter, the order of preinitiation complex assembly at a promoter (e.g., initial binding by TBP, initial binding by IIB, or concerted binding by TBP and IIB), the ratelimiting step in transcription initiation at a promoter, and-given the observation that several transcriptional activators interact with IIB (Roberts et al. 1995 and references therein)-the responsiveness of a promoter to specific transcriptional activators. It also is possible that IIB-BRE interaction will play a role in determining the upstream $\rightarrow$ downstream directionality of preinitiation complex assembly and transcription initiation, supplementing the TBP-TATA interaction, which, because of its high degree of twofold symmetry (J. Kim et al. 1993; Y. Kim et al. 1993), is insufficient to determine directionality (Xu et al. 1991; J. Cox, M. Hayward, J. Sanchez, L. Gegnas, S. van der Zee, J. Dennis, P. Sigler, and A. Schepartz, in prep.). Finally, it is possible that IIB-BRE interaction will play a role, possibly a dominant role, in preinitiation complex assembly and transcription initiation at TATA-less promoters (see Weis and Reinberg 1997). The effects of the upstream el ement (UP element) in prokaryotic transcription provide an informative precedent for effects of a supplementary promoter element on multiple aspects of transcription initiation and transcriptional activation (for review, see Busby and Ebright 1994).

A search of the Eukaryotic Promoter Database (EPD) (Bucher 1996) reveal s that, of Pol II-dependent vertebrate promoters that have a consensus TATA element at a consensus position $\left(T_{1} A_{2} T_{3} A_{4}\right.$ with $T_{1}$ at position -32 , $-31,-30,-29$, or -28 relative to the principal transcription start; 315 promoters), $12 \%$ have a 5 -of-7 or better match to the consensus BRE immediately upstream of the TATA el ement, 34\% have a 4-of-7 or better match to the consensus BRE immediately upstream of the TATA 


\begin{tabular}{|c|c|c|c|c|c|c|c|c|c|c|c|c|c|c|c|c|c|c|c|c|c|}
\hline \multirow[b]{2}{*}{ CAP } & \multirow[b]{2}{*}{$\mathrm{T}$} & \multicolumn{8}{|c|}{$\mathrm{H}$} & \multicolumn{3}{|c|}{$\mathrm{T}$} & \multicolumn{9}{|c|}{ H } \\
\hline & & $\mathrm{R}$ & $Q$ & E & I & $G$ & $Q$ & $I$ & V & G & C & $\mathrm{S}$ & $\dot{\mathrm{R}}$ & $\dot{\mathrm{E}}$ & $\mathrm{T}$ & $\mathrm{V}$ & $\dot{\mathrm{G}}$ & $\stackrel{\bullet}{\mathrm{R}}$ & $I$ & L & $\mathrm{K}$ \\
\hline Trp Repressor & $\mathrm{s}$ & $Q$ & $\mathrm{R}$ & $\mathrm{E}$ & L & $\mathrm{K}$ & $\hat{N}$ & $\mathbf{B}$ & L & G & A & G & I & $\bar{A}$ & $\mathrm{~T}$ & I & $\mathrm{T}$ & $\mathbf{R}$ & G & $\mathrm{s}$ & $\mathrm{N}$ \\
\hline Lac Repressor & $\mathrm{T}$ & $\mathrm{L}$ & $\mathrm{Y}$ & D & $\mathrm{V}$ & A & E & $\mathrm{Y}$ & A & G & $\mathrm{v}$ & $s$ & $Y$ & $Q$ & $\mathrm{~T}$ & $\mathrm{v}$ & $\mathbf{s}$ & $\mathbf{R}$ & $\mathrm{V}$ & $\mathrm{V}$ & $\mathrm{N}$ \\
\hline Lambda Repressor & $s$ & Q & B & $\mathrm{s}$ & V & A & D & $\mathrm{K}$ & M & G & M & G & $Q$ & $\mathrm{~S}$ & G & $\mathrm{v}$ & G & A & $\mathrm{L}$ & $\mathrm{F}$ & $\mathrm{N}$ \\
\hline Lambda Cro & G & $\hat{Q}$ & $\mathrm{~T}$ & $\mathrm{~K}$ & $\mathrm{~T}$ & A & K & D & $\mathrm{L}$ & G & $\mathrm{v}$ & $\mathrm{Y}$ & $\mathrm{Q}$ & $\mathrm{S}$ & A & I & $\mathrm{N}$ & $\mathrm{K}$ & A & I & H \\
\hline 434 Repressor & $\mathrm{N}$ & $\bar{Q}$ & A & $\mathrm{E}$ & L & A & Q & K & $\mathrm{V}$ & G & $\mathrm{T}$ & $\mathrm{T}$ & $\hat{Q}$ & $Q$ & s & $\mathbf{I}$ & $\mathrm{E}$ & $\mathbf{Q}$ & $\mathrm{L}$ & $\mathrm{E}$ & $\mathrm{N}$ \\
\hline $434 \mathrm{Cro}$ & $\mathrm{T}$ & $\hat{Q}$ & $\mathrm{~T}$ & $\mathrm{E}$ & L & A & $\mathrm{T}$ & $\mathrm{K}$ & A & G & $\mathrm{v}$ & $\mathrm{K}$ & Q & $\hat{Q}$ & s & I & $Q$ & $\mathrm{~L}$ & I & $\mathrm{E}$ & A \\
\hline P22 Repressor & A & $\mathrm{Q}$ & A & A & L & G & $\mathrm{K}$ & M & $\mathrm{V}$ & G & $\mathrm{v}$ & $\mathrm{s}$ & $\mathrm{N}$ & V & A & I & S & $Q$ & w & $Q$ & $\mathrm{R}$ \\
\hline P22 Cro & $\mathrm{T}$ & $Q$ & $\mathbf{R}$ & A & v & A & K & A & L & G & I & $S$ & D & A & A & $\mathrm{v}$ & $\mathrm{S}$ & $\hat{Q}$ & w & $\mathrm{K}$ & E \\
\hline
\end{tabular}

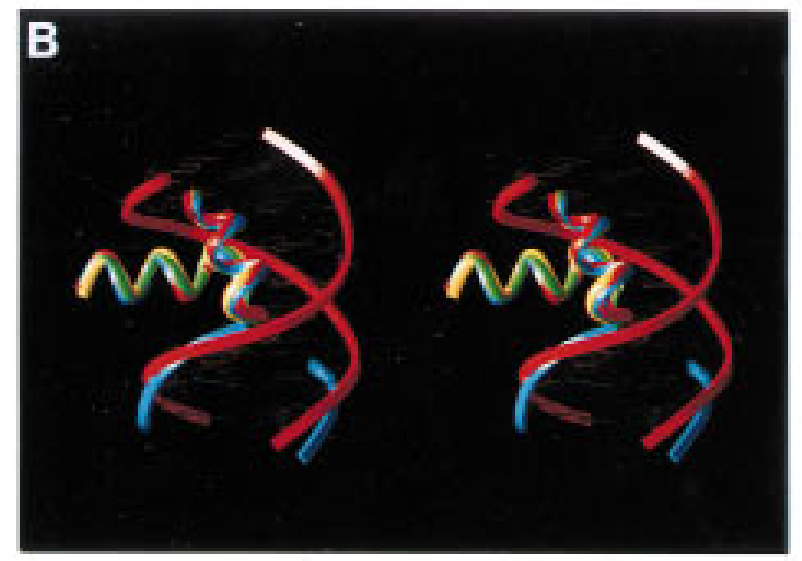

Figure 6. IIB recognizes the new sequence element through a helixturn-helix motif: structural evidence. (A) Amino acid sequences of helices 4' and 5' of IIB (residues 270-290 of IIB; Bagby et al. 1995; Nikolov et al. 1995) and known HTHs (residues -1-20 of each HTH; Pabo and Sauer 1992). Amino acids conserved among known HTHs are highlighted in yellow; positions of amino acids that contact DN A base pairs in known structures of HTH-DNA complex structures are marked with filled circles. (B,C) Superimposition of helices $4^{\prime}$ and $5^{\prime}$ of IIB (blue; Nikolov et al. 1995; coordinates kindly supplied by S. Burley, Rockefeller University, N ew York, NY) on the HTHs of CAP (yellow; Parkinson et al. 1996), $\lambda$ repressor (green; Beamer and Pabo 1992; coordinates obtained from Brookhaven Protein Data Bank, accession code 1LMB), and Trp repressor (red; Otwinowski et al. 1988; coordinates obtained from Brookhaven Protein Data Bank, accession code 1TRO) (two orthogonal views). The 3 nucleotide pairs upstream of the TATA element present in the crystallographic structure of the IIBC-TBPc-TATA complex are shown in ribbon representation and colored blue; these nucl eotide pairs correspond to positions -34 to -32 of the adenovirus major late promoter (position -32 at bottom in B). $\mathrm{N}$ ine nucleotide pairs in the Trp repressor-DNA complex are shown in ribbon representation and colored red. (D) Superimposition of helices $3^{\prime}-5^{\prime}$ of IIB (blue) on helices C-E of Trp repressor (red). (E) Structure of the IIBC-TBPC-TATA complex (N ikolov et al. 1995; Fig. 1) showing helices 4' and 5' of IIB (dark blue), the nucleotide pair corresponding to position -34 of the adenovirus major late promoter (arrow), and the projected location of the nucleotide pair corresponding to position -37 of the adenovirus major late promoter (arrow). IIBC is blue, TBP is white, the DN A nontemplate strand is bright red, and the DNA template strand is dark red.
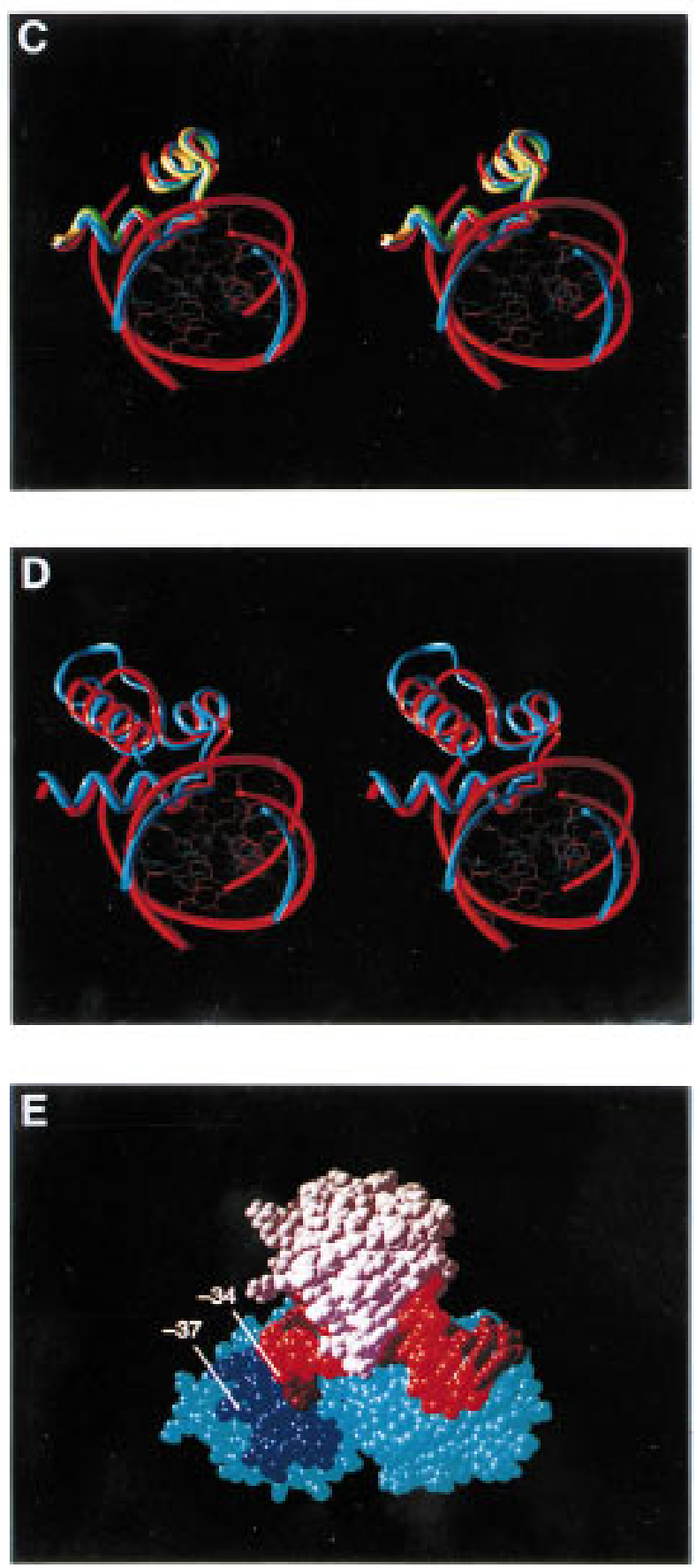
A

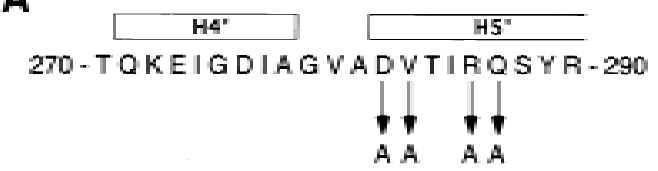

B

\begin{tabular}{|c|c|}
\hline Protein & 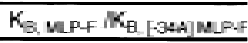 \\
\hline nit 19 & 5 \\
\hline [Ala 282]-HIt & 4 \\
\hline |Ala 2Ba|-II & 0.8 \\
\hline Ala 286]-III & 0.8 \\
\hline [Ala 287$]-11$ & $\frac{1}{4}$ \\
\hline
\end{tabular}

C

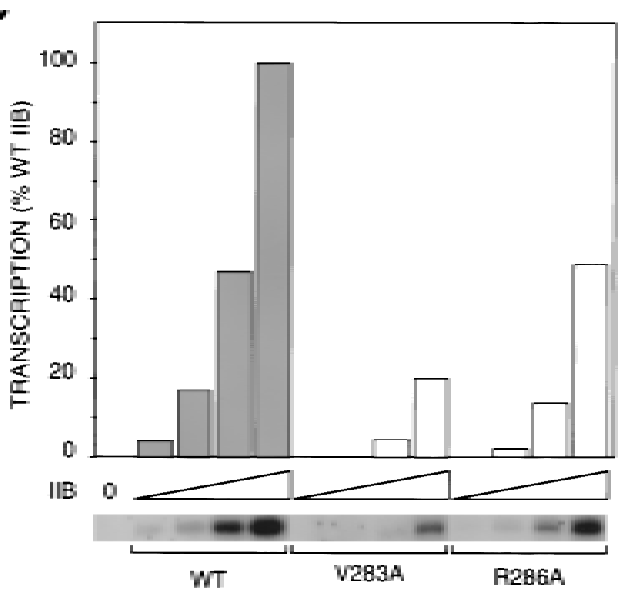

Figure 7. IIB recognizes the new sequence element through a HTH motif: functional evidence. (A) Substitutions of amino acids of IIB that correspond to base-pair-contacting amino acids of HTH DNA-binding proteins (see Fig. 6A). (B) Effects of substitutions on specificity between $G: C$ and $A: T$ at position -34 of the adenovirus major late promoter. Data are from fluorescence anisotropy assays of IIB-TBPC-DN A complex formation. (C) Effects on transcription initiation at the adenovirus major late promoter. Data are from run-off transcription assays. IIB and IIB derivatives were at $1,2,4$, and $8 \mathrm{~nm}$.

element, and $40 \%$ have the consensus nucleotide pair $\mathrm{G}: \mathrm{C} 3$ nucleotide pairs upstream of the TATA el ement. Of Pol II-dependent vertebrate promoters that do not contain a consensus TATA element at a consensus position (550 promoters), $15 \%$ have a 6 -of-7 or better match to the consensus BRE between positions -41 and -27 , and $62 \%$ have a $5-$ of -7 or better match to the consensus BRE between positions -41 and -27 . All of these frequencies are significantly higher than those expected by chance $(0.94 \%, 1.7 \%$, and $25 \% ; 2.9 \%$ and $8.5 \%$, respectively), consistent with the hypothesis that BRE is functionally significant in vivo. The observation that a substantial minority, rather than a majority, of Pol II-dependent promoters contains a consensus or near-consensus BRE accounts for the fact that the BRE was not identified through global sequence alignments of Pol II-dependent promoters.

The amino acid sequence of helices $4^{\prime}$ and $5^{\prime}$ of IIBthe region shown here to fold as an HTH (Fig. 6)-is conserved in IIB from all eukaryotes for which sequence data are avai lable and in transcription factor $B$ (TFB) from all archaea for which sequence data are available (9 IIB and 5 TFB sequences in SWISSPROT), suggesting that this region folds as an HTH in all cases. Val-283 and Arg-286 of IIB - the amino acids shown here to determine specificity at the $\mathrm{G}: \mathrm{C}$ nucleotide pair corresponding to position -34 of the adenovirus major late promoter (Fig. 7)-are invariant in IIB from all eukaryotes, except plants and fungi, and in TFB from all archaea, suggesting that IIB from all eukaryotes, possibly excluding plants and fungi, and TFB from all archaea may have related DNA-binding specificities. Consistent with these suggestions, helices $4^{\prime}$ and $5^{\prime}$ of TFB from the archaeon Pyrococcus woesi fold as a canonical HTH (Kosa et al. 1997; coordinates obtained from Brookhaven Protein Data Bank, accession code 1AIS), and results obtained while this manuscript was in preparation suggest that TFB from the archaeon Sulfol obus shibatae recognizes a promoter element located immediately upstream of the TATA el ement and containing a critical $\mathrm{G}: \mathrm{C}$ nucleotide pair (S. Qureshi and S. Jackson, pers. comm.).

The starting point for this work was the observation that IIB makes extensive interactions with the DN A major groove (Lee and Hahn 1995; N ikolov et al. 1995; Lagrange et al. 1996). Site-specific protein-DNA photocross-linking indicates that at least three other components of the human Pol II-dependent preinitiation complex make extensive interactions with the DN A major groove (i.e., IIA, IIF, and Pol II) (Lagrange et al. 1996; Kim et al. 1997). It will be important to investigate whether there exist promoter elements recognized by IIA, IIF, and Pol II. (Preliminary binding site selection results support the existence of a promoter element recognized by IIA; H. Tang, D. Reinberg, and R.H. Ebright, unpubl.). The possible existence of additional promoter elements is attractive in that it would enable the "encoding" in promoter DNA of a wide range of promoter strengths and promoter characteristics, including responsiveness to specific transcriptional activators and repressors (see also Shen and Green 1997). If documented, the existence of additional promoter elements would require revision of the current view of the promoter DNA as an information-poor scaffold for preinitiation complex assembly to a new view of promoter DNA as an information-rich participant in, and director of, preinitiation complex assembly.

\section{Materials and methods}

IIB derivatives

Plasmids encoding amino-terminally hexahistidine-tagged human IIB (20 nonnative amino acids followed by amino acids 1-316 of IIB; pNHislIB) or amino-terminally hexahistidinetagged human IIBC (23 nonnative amino acids followed by amino acids $112-316$ of IIB; pN HisllBC) under control of the bacteriophage T7 gene 10 promoter were constructed by replacement of the $\mathrm{Nhel-BamHI}$ segment of pET 28a(+) (N ovagen) by the Nhel-BamHI segments of phIIB and phlIB $\Delta 4-111$ (Ha et al. 1993), respectively. Substitutions were introduced into 
pN HisllB by the method of Kunkel et al. (1991). Cultures of Escherichia coli strain BL21(DE3) (N ovagen) transformed with pNHisllB, pNHisllB derivative, or pNHisllBc were shaken at $37^{\circ} \mathrm{C}$ in 1 liter of LB (Miller 1972) plus $40 \mu \mathrm{g} / \mathrm{ml}$ of kanamycin until $\mathrm{OD}_{600}=0.6$, induced by addition of IPTG to $1 \mathrm{~mm}$, and shaken for an additional $3 \mathrm{hr}$ at $37^{\circ} \mathrm{C}$. Cultures were harvested by centrifugation $\left(4000 \mathrm{~g} ; 15 \mathrm{~min}\right.$ at $4^{\circ} \mathrm{C}$ ), cell pellets were resuspended in $20 \mathrm{ml}$ of buffer A [20 mM Tris- $\mathrm{HCl}(\mathrm{pH} 7.9), 500$ $\mathrm{mm} \mathrm{NaCl}, 5 \mathrm{~mm}$ imidazole, $0.1 \% \mathrm{NP}-40$ ], cells were lysed by sonication, and lysates were cleared by centrifugation (30,000g; $30 \mathrm{~min}$ at $4^{\circ} \mathrm{C}$ ). Samples were adsorbed onto a $1.5-\mathrm{ml}$ column of $\mathrm{Ni}^{2+}$-NTA agarose (Qiagen) in buffer $\mathrm{A}$ at $4^{\circ} \mathrm{C}$, washed with 25 $\mathrm{ml}$ of buffer $\mathrm{A}$, washed with $50 \mathrm{ml}$ of buffer A plus $40 \mathrm{~mm}$ imidazole, eluted with $16 \mathrm{ml}$ of buffer A plus $300 \mathrm{~mm}$ imidazole, desalted into or dialyzed against $10 \mathrm{~mm}$ Tris- $\mathrm{HCl}(\mathrm{pH} 7.9), 500$ $\mathrm{mM} \mathrm{KCl}, 0.2 \mathrm{~mm}$ EDTA, $0.2 \mathrm{~mm}$ PMSF, and 20\% glycerol, and stored in aliquots at $-80^{\circ} \mathrm{C}$. The yield was $5-10 \mathrm{mg}$ and the purity was $>98 \%$.

\section{TBP, IIE, IIF, IIH, RNA Pol II}

Recombinant human TBP, recombinant human TBPc, recombinant human IIE, recombinant human IIF, human IIH (M ono-S and $0.5 \mathrm{M}$ phenyl-Superose fractions), and human Pol II (DEAE5PW fraction) were prepared as described (Lu et al. 1991; Peterson et al. 1991; Flores et al. 1992; Ha et al. 1993; Wang et al. 1993; Heyduk et al. 1996; Tang et al. 1996).

\section{Binding site selection, round 1}

Reaction mixtures for round 1 , cycle 1 , contained $(20 \mu \mathrm{l}): 1 \mathrm{nM}$ ${ }^{32} \mathrm{P}$-end-labeled DN A fragment $\left[\mathrm{N}_{12}\right] \mathrm{M} \mathrm{LP}$ [10 Bq/fmole; positions -43 to -12 of the adenovi rus major late promoter, with -43 to -32 randomized, flanked by $16 \mathrm{bp}$ of nonnative sequence upstream and $15 \mathrm{bp}$ of nonnative sequence downstream; prepared by annealing of 5'-AGACGGATCCATTCGAN N N N N N N N N N N NTATAAAAGGGGGTGGGGGCGCTGTAGGAATTCGGA-3' and primer A (5'-TCCGAATTCCTACAG-3') followed by extension with Sequenase (Amersham) and $[\alpha-$ ${ }^{32} \mathrm{P}$ ]dNTPs], $10 \mathrm{~nm}$ TBPc, 0.5-20 nм IIB, $20 \mathrm{~mm}$ Tris- $\mathrm{HCl}$ (pH 7.9), $20 \mathrm{~mm}$ HEPES- $\mathrm{NaOH}$ (pH 7.9), $60 \mathrm{~mm} \mathrm{KCl}, 10 \mathrm{~mm} \mathrm{M} \mathrm{gCl}$, $8 \mathrm{~mm}\left(\mathrm{~N} \mathrm{H}_{4}\right)_{2} \mathrm{SO}_{4}, 0.5 \mathrm{~mm}$ DTT, $0.05 \mathrm{~mm}$ EDTA, $0.1 \mathrm{~mm}$ PMSF, $25 \mu \mathrm{g} / \mathrm{ml}$ poly[d(G-C)]:poly[d(G-C)] (average molecular mass, $800 \mathrm{kD}$; Pharmacia), $25 \mathrm{\mu g} / \mathrm{ml}$ of PEG (average molecular mass, $8 \mathrm{kD}$ ), and $5 \%$ glycerol. After reaction for $30 \mathrm{~min}$ at $30^{\circ} \mathrm{C}$, reaction products were separated by nondenaturing el ectrophoresis as in Tang et al. (1996), and gels were dried, autoradiographed, and phosphorimaged. The reaction containing 2 nM IIB resulted in $\sim 2 \%$ saturation of IIB-TBPC-DNA complex formation. For this reaction, the band corresponding to the IIB-TBPCDNA complex was excised, and the DNA in the band was eluted by boiling $10 \mathrm{~min}$ in $100 \mu \mathrm{l}$ of water, extracted with phenol/chloroform/isoamyl al cohol (25:24:1) after addition of 5 $\mu \mathrm{g}$ of yeast tRNA as carrier, ethanol precipitated, amplified by PCR with primer A, primer B (5'-AGACGGATCCATTCGA$\left.3^{\prime}\right)$, Taq DNA polymerase, and $\left[\alpha^{-}{ }^{32} \mathrm{P}\right] \mathrm{dNTPS}$, and purified by $12 \%$ PAGE. The selected, amplified DNA was subjected to three additional cycles of selection and amplification, in each cycle selecting DNA from reactions with IIB concentrations that resulted in $2 \%-4 \%$ saturation of IIB-TBPc-DNA complex formation $(0.5,0.5$, and $0.1 \mathrm{nM}$ IIB in cycles 2,3 , and 4 , respectively). Selected, amplified DNA fragments from cycle 4 were treated with EcoRI and BamHI, ligated into EcoRI/BamHI-digested plasmid pBluescript II SK(-) (Stratagene), cl oned by transformation into strain XL1-Blue (Stratagene), and sequenced using the T7 promoter primer (Stratagene).
Binding site selection, round 2

Reaction mixtures for round 2 , cycle 1 , contained $(20 \mu \mathrm{l})$ : 50 pM ${ }^{32} \mathrm{P}$-end-labeled DNA fragment $\left[\mathrm{N}_{5} \mathrm{GN}_{2}\right] \mathrm{MLP} 56[150 \mathrm{~Bq} /$ fmole; positions -53 to +3 of the adenovirus major late promoter, with -39 to $-35,-33$, and -32 randomized; prepared by annealing of 5'-GATCGAATTCCGGAGCCGGGTGTTCCTGAN N N N N GNNTATAAAAGGGGGTGGGGGCG-3' and 5'-GATGGGATCCATTAGAGTGAGGACGAACGCGCCCCCACCCCCTTTTA-3', extension with T4 DNA polymerase and dNTPS, PCR with primer C (5'-GATCGAATTCCGGAG$\left.3^{\prime}\right)$, primer D (5'-GATGGGATCCATTAG-3'), Taq DNA polymerase, and dNTPs, and radiophosphorylation with T4 polynucl eotide kinase and [ $\gamma^{-32}$ P]ATP], 10 nм TBP, 0.5-80 nм IIB, 5 $\mathrm{mm}$ Tris- $\mathrm{HCl}$ (pH 8.0), $60 \mathrm{~mm} \mathrm{KCl}, 5 \mathrm{~mm} \mathrm{M} \mathrm{gCl} 2,1 \mathrm{~mm}$ DTT, 25 $\mu \mathrm{g} / \mathrm{ml}$ poly[d(G-C)]:poly[d(G-C)] (average molecular mass, 800 kD; Pharmacia), $100 \mu \mathrm{g} / \mathrm{ml}$ of BSA, $0.1 \%$ Brij-58, and $4 \%$ glycerol. Reactions were performed, and DNA was isolated and amplified, essentially as in binding site selection, round 1 , except that el ectrophoresis was performed at $4^{\circ} \mathrm{C}$ in gels containing 1 $\mathrm{mM} \mathrm{Mg}(\mathrm{OAC})_{2}$ and not containing glycerol. Seven cycles of selection and amplification were performed, in the first cycle selecting DNA from reactions with IIB concentrations that resulted in $\sim 10 \%$ saturation of IIB-TBP-DN A complex formation, and in subsequent cycles selecting DN A from reactions with IIB concentrations that resulted in $2 \%-4 \%$ saturation $(7,1,0.2$, $0.06,0.01,0.02$, and $0.05 \mathrm{~nm}$ IIB). After each cycle, DNA fragment pools were sequenced directly using primer $C$ (Blackwell and Weintraub 1990). After the seventh cycle, DN A fragments were digested with EcoRI and BamHI, ligated into EcoRI/ BamHI-digested plasmid pBluescript II KS( $\rightarrow$ (Stratagene), cloned by transformation into strain XL1-Blue (Stratagene), and sequenced using primer $\mathrm{C}$.

\section{Electrophoretic mobility shift DNA-binding experiments}

Electrophoretic mobility shift DNA-binding experiments were performed as in Maldonado et al. (1990), using $0.1 \mathrm{nM}{ }^{32} \mathrm{P}-\mathrm{la}$ beled DNA fragment [ $\mathrm{N}_{12}$ ] MLP or [SELECT-1]MLP (10 Bq/ fmole; positions -43 to -12 of the $\mathrm{N}_{12}$-randomized or pooled round-1-sel ected adenovirus major late promoter, flanked by 16 bp of nonnative sequence upstream and $15 \mathrm{bp}$ of nonnative sequence downstream; see above) or $0.1 \mathrm{nM}{ }^{32} \mathrm{P}$-end-label ed DN A fragment MLP56, [N 8 ]M LP56, [ $\mathrm{N}_{5} \mathrm{GN}_{2}$ ] M LP56, or [SELECT2]MLP56 (500 Bq/fmole; positions -53 to +3 of the wild-type, $\mathrm{N}_{8}$-randomized, $\mathrm{N}_{5} \mathrm{GN}_{2}$-randomized, or round-2-selected adenovirus major late promoter; prepared by PCR of the corresponding synthetic DN A fragments or pooled round-2-selected DN A fragments with ${ }^{32} \mathrm{P}$-end-labeled primer $\mathrm{C}$ and unlabeled primer D), $30 \mathrm{~nm}$ TBP, and 0.05-20 nм IIB.

\section{Fluorescence anisotropy DNA binding experiments}

Assay mixtures contained $(1.2 \mathrm{ml}$ in $12 \times 75 \mathrm{~mm}$ borosilicate glass disposable culture tubes): 0.3-1 nM fluorescein-end-label ed DN A fragment M LP-F, [SELECT-2CON S]M LP-F, [-34A ]M LP-F, or [-37A; $-34 \mathrm{~A}] \mathrm{M} L \mathrm{P}-\mathrm{F}$ (positions -43 to -19 of the wild-type, consensus round-2-selected, $-34 \mathrm{~A}$, or $-37 \mathrm{~A} ;-34 \mathrm{~A}$ adenovirus major late promoter; prepared as described for M LP24FL in Heyduk et al. 1996), 0 or $80 \mathrm{~nm} \mathrm{TBPc,} 20 \mathrm{~mm}$ Tris- $\mathrm{HCl}$ (pH 8.0), 20 mM HEPES- $\mathrm{NaOH}$ (pH 8.0), $60 \mathrm{~mm} \mathrm{KCl}, 10 \mathrm{~mm} \mathrm{M} \mathrm{gCl}, 8 \mathrm{~mm}$ $\left(\mathrm{NH}_{4}\right)_{2} \mathrm{SO}_{4}, 0.05 \mathrm{~mm}$ EDTA, $0.5 \mathrm{~mm}$ DTT, $0.1 \mathrm{~mm}$ PMSF, 7 $\mu \mathrm{g} / \mathrm{ml}$ of poly[d(G-C)]:poly[d(G-C)] (average molecular mass,

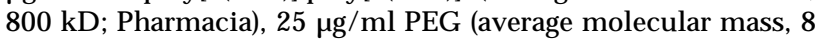
$\mathrm{kD}), 100 \mu \mathrm{g} / \mathrm{ml}$ of BSA, $0.1 \% \mathrm{NP}-40$, and $5 \%$ glycerol. Assay mixtures were incubated $25 \mathrm{~min}$ at $28^{\circ} \mathrm{C}\left(25^{\circ} \mathrm{C}\right.$ for IIB-DN A and 
IIBC-DN A complex formation) and then titrated by successive addition of $0.5-2 \mu \mathrm{l}$ aliquots of IIB or IIBC in the same buffer at $28^{\circ} \mathrm{C}\left(25^{\circ} \mathrm{C}\right.$ for IIB-DNA and IIBC-DNA complex formation). Fluorescence anisotropy was determined using a PanVera Beacon fluorescence polarization instrument at the start of the titration and $4 \mathrm{~min}$ after each successive addition in the titration. Equilibrium-binding constants were calculated using nonlinear regression (Gunasekera et al. 1992).

\section{Protein-DNA photo-cross-linking}

Protein-DN A photo-cross-linking was performed as in Lagrange et al. (1996), using 0 or 6 nм TBP and 20 nм IIB or IIBc.

\section{Transcription experiments}

Reaction mixtures for abortive initiation experiments contained $(20 \mu \mathrm{l}): 1.0 \mathrm{nM}$ DNA fragment MLP112, [N 8 ]MLP112, [N ${ }_{5} \mathrm{GN}_{2}$ ]M LP112, [SELECT-2]M LP112 [positions -68 to +44 of the wild-type, $\mathrm{N}_{8}$-randomized, $\mathrm{N}_{5} \mathrm{GN}_{2}$-randomized, or round-2selected adenovirus major late promoter; prepared by add-on PCR of the corresponding synthetic DNA fragments or pooled round-2-selected DNA fragments; concentration determined flurometrically using PicoGreen reagent (M olecular Probes)] or $1.0 \mathrm{nM}$ DNA fragment MLP-TI or [-37A;-34A]M LP-TI (positions -45 to +9 of the wild-type or $-37 A ;-34 A$ adenovirus major late promoter flanked by nonnative sequence and with positions -23 to -6 replaced by nonnative sequence; prepared from corresponding plasmid clones), 20 nM TBP, 0.02-4 nM IIB, 20 nM IIF, $30 \mathrm{~nm}$ IIE, $10 \mathrm{~nm}$ IIH (Mono-S fraction), $20 \mathrm{~nm}$ RNA Pol II (DEAE-5PW fraction), $1 \mathrm{~mm}\left[\alpha^{-}{ }^{32} \mathrm{P}\right] \mathrm{CTP}$ (30 Bq/pmole), $1 \mathrm{~mm}$ ATP, $10 \mathrm{~mm}$ Tris- $\mathrm{HCl}(\mathrm{pH} 7.8), 10 \mathrm{~mm}$ HEPES-KOH (pH 7.8), 50 $\mathrm{mM} \mathrm{KCl}, 4 \mathrm{~mm} \mathrm{M} \mathrm{gCl} 2,4 \mathrm{~mm}\left(\mathrm{~N} \mathrm{H}_{4}\right)_{2} \mathrm{SO}_{4}, 0.1 \mathrm{~mm}$ EDTA, $0.7 \mathrm{~mm}$ DTT, $400 \mathrm{U} / \mathrm{ml}$ of rRN asin (Promega), and $10 \%$ glycerol. Reactions were initiated by addition of $\left[\alpha{ }^{32} \mathrm{P}\right] \mathrm{CTP}$ and ATP, were allowed to proceed for $30 \mathrm{~min}$ at $28^{\circ} \mathrm{C}$, and were terminated and analyzed as in Goodrich and Tjian (1994). Reaction mixtures for run-off transcription experiments contained $(20 \mu \mathrm{l}): 2 \mathrm{nM}$ plasmid $\mathrm{p} \Delta \mathrm{ML}$, which carries the adenovirus major late promoter followed by a 210-nucleotide G-less cassette [derivative of pML( $\left.\mathrm{C}_{2} \mathrm{AT}\right) \Delta-50$ (Sawadogo and Roeder 1985) with shortened G-less cassette], 20 mm TBP, 1-8 nM IIB or derivative, 20 nM IIF, $30 \mathrm{~nm}$ IIE, $50 \mathrm{~nm}$ IIH (0.5 м phenyl-Superose fraction), $50 \mathrm{~nm}$ Pol II (DEAE-5PW fraction), $0.15 \mathrm{~mm}\left[\alpha^{-32} \mathrm{P}\right] \mathrm{UTP}, 0.6 \mathrm{~mm}$ ATP, 0.6 $\mathrm{mm}$ CTP, $1000 \mathrm{U} / \mathrm{ml}$ of RNase T1, $20 \mathrm{~mm}$ HEPES- $\mathrm{NaOH}(\mathrm{pH}$ 7.9), $50 \mathrm{~mm} \mathrm{KCl}, 10 \mathrm{~mm}\left(\mathrm{~N} \mathrm{H}_{4}\right)_{2} \mathrm{SO}_{4}, 10 \mathrm{~mm} \beta$-mercaptoethanol, $20 \mathrm{mg} / \mathrm{ml}$ of PEG (average molecular mass, $8 \mathrm{kD}$ ), and $10 \%$ glycerol. Reactions were initiated by addition of $\left[\alpha^{-32} \mathrm{P}\right] U T \mathrm{P}$, ATP, and CTP, were allowed to proceed for $20 \mathrm{~min}$ at $28^{\circ} \mathrm{C}$, and were terminated by addition of $80 \mu \mathrm{l}$ of $100 \mathrm{~mm}$ sodium acetate (pH 5.5), $10 \mathrm{~mm}$ EDTA, $1 \mathrm{mg} / \mathrm{ml}$ of yeast tRN A, and $0.2 \%$ SDS. Reaction products were phenol/chloroform extracted, ethanol precipitated, and analyzed by $8 \mathrm{~m}$ urea-15\% PAGE followed by phosphorimaging and autoradiography.

\section{Acknowledgments}

We thank S. Burley for atomic coordinates and L. Weis for database searches. This work was supported by $\mathrm{N}$ ational Institutes of Health (NIH) grant GM 37120 and a Howard Hughes Medical Institute Investigatorship to D.R. and by NIH grant GM 53665 to R.H.E. A.N.K. was supported in part by the State Scholarship Foundation, Greece, and the Hellenic Medical Society of N ew York.

The publication costs of this article were defrayed in part by payment of page charges. This article must therefore be hereby marked "advertisement" in accordance with 18 USC section 1734 solely to indicate this fact.

\section{References}

Bagby, S., S. Kim, E. Maldonado, K. Tonk, D. Reinberg, and M. Ikura. 1995. Solution structure of the carboxy-terminal core domain of human TFIIB: Similarity to cyclin A and interaction with TATA-binding protein. Cell 82: 857-867.

Beamer, L. and C. Pabo. 1992. Refined $1.8 \AA$ crystal structure of the lambda repressor-operator complex. J. Mol. Biol. 227: 177-196.

Blackwell, T. and H. Weintraub. 1990. Differences and similarities in DNA-binding preferences of MyoD and E2A protein complexes revealed by binding site selection. Science 250: 1104-1110.

Blackwell, T., L. Kretzner, E. Blackwood, R. Eisenman, and H. Weintraub. 1990. Sequence-specific DNA binding by the cMyc protein. Science 250: 1149-1151.

Bucher, P. 1996. The Eukaryotic Promoter Database EPD, $E M B L$, nucleotide sequence data library, rel ease 48. European Bioinformatics Institute, Cambridge, UK.

Burke, T. and J. Kadonaga. 1996. Drosophila TFIID binds to a conserved downstream basal promoter element that is present in many TATA-box-deficient promoters. Genes \& Dev. 10: 711-724.

Busby, S. and R. Ebright. 1994. Promoter structure, promoter recognition, and transcription activation in prokaryotes. Cell 79: 743-746.

Corden, J., B. Wasylyk, A. Buchwalder, P. Sassone-Corsi, C. Kedinger, and P. Chambon. 1980. Promoter sequences of eukaryotic protein-encoding genes. Science 209: 1406-1414.

Dodd, B. and J. Egan. 1990. Improved detection of helix-turnhelix DN A-binding motifs in protein sequences. Nucleic Acids Res. 18: 5019-5026.

Ebright, R. 1991. Identification of amino acid-base pair contacts by genetic methods. Methods Enzymol. 208: 620-640.

Flores, O., H. Lu, and D. Reinberg. 1992. Factors involved in specific transcription initiation by mammalian RNA polymerase II: Identification and characterization of factor IIH. J. Biol. Chem. 267: 2786-2793.

Goodrich, J. and R. Tjian. 1994. Transcription factors IIE and IIH and ATP hydrolysis direct promoter clearance by RN A polymerase II. Cell 77: 145-156.

Gunasekera, A., Y. Ebright, and R. Ebright. 1992. DNA-sequence determinants for binding of the Escherichia coli catabolite gene activator protein. J. Biol. Chem. 267: 1471314720.

Ha, I., S. Roberts, E. Maldonado, X. Sun, L.-U. Kim, M. Green, and D. Reinberg. 1993. Multiple functional domains of human transcription factor IIB: Distinct interactions with two general transcription factors and RN A polymerase. Genes \& Dev. 7: 1021-1032.

Heyduk, T., Y. M a, H. Tang, and R. Ebright. 1996. Fluorescence anisotropy: Rapid, quantitative assay for protein-DNA and protein-protein interaction. Methods Enzymol. 274: 492502.

Kim, J., D. Nikolov, and S. Burley. 1993. Co-crystal structure of TBP recognizing the minor groove of a TATA el ement. Nature 365: 520-527.

Kim, Y., J. Geiger, S. Hahn, and P. Sigler. 1993. Crystal structure of a yeast TBP/TATA-box complex. Nature 365: 512-520.

Kim, T.-K., T. Lagrange, Y.-H. Wang, J. Griffith, D. Reinberg, and R. Ebright. 1997. Trajectory of DNA in the RNA poly- 
merase II transcription preinitiation complex. Proc. Natl. Acad. Sci. 94: 12268-12273.

Kosa, P., G. Ghosh, B. DeDecker, and P. Sigler. 1997. The 2.1- $\AA$ crystal structure of an archaeal preinitiation complex: TATA-box-binding protein/transcription factor (II)B core/ TATA-box. Proc. Natl. Acad. Sci. 94: 6042-6047.

Kunkel, T., K. Bebenek, and J. McClary. 1991. Efficient sitedirected mutagenesis using uracil-containing DNA. Methods Enzymol. 204: 125-138.

Lagrange, T., T.-K. Kim, G. Orphanides, Y. Ebright, R. Ebright, and D. Reinberg. 1996. High-resolution mapping of nucleoprotein complexes by site-specific protein-DNA photocrosslinking: Organization of the human TBP-TFIIA-TFIIB-DNA quaternary complex. Proc. Natl. Acad. Sci. 93: 10620-10625.

Lee, S. and S. Hahn. 1995. A model for TFIIB binding to the TBP-DN A complex. Nature 376: 609-612.

Lu, H., O. Flores, R. Weinmann, and D. Reinberg. 1991. The nonphosphorylated form of RNA polymerase II preferentially associates with the preinitiation complex. Proc. Natl. Acad. Sci. 88: 10004-10008.

Lundblad, J., M. Laurance, and R. Goodman. 1996. Fluorescence polarization analysis of protein-DNA and protein-protein interactions. Mol. Endocrinol. 10: 607-612.

Maldonado, E., I. Ha, P. Cortes, L. Weis, and D. Reinberg. 1990. Role of transcription factors TFIIA, TFIID, and TFIIB during formation of a transcription-competent complex. Mol. Cell. Biol. 10: 6335-6347.

Mavrothal assitis, G., G. Beal, and T. Papas. 1990. Defining target sequences of DN A-binding proteins by random selection and PCR: Determination of the GCN 4 binding sequence repertoire. DNA 9: 783-788.

Miller, J. 1972. Experiments in molecular genetics. Cold Spring Harbor Laboratory, Cold Spring Harbor, NY.

Nikolov, D. and S. Burley. 1997. RNA polymerase II transcription initiation: A structural view. Proc. Natl. Acad. Sci. 94: 15-22.

Nikolov, D., H. Chen, E. Halay, A. Usheva, K. Hisatake, D. Lee, R. Roeder, and S. Burley. 1995. Crystal structure of a TFIIBTBP-TATA-element ternary complex. Nature 377: 119-128.

Oliphant, A., C. Brandl, and K. Struhl. 1989. Defining the sequence specificity of DNA-binding proteins by selecting binding sites from random-sequence oligonucleotides: Analysis of yeast GCN 4 protein. Mol. Cell. Biol. 9: 29442949.

Orphanides, G., T. Lagrange, and D. Reinberg. 1996. The general transcription factors of RNA polymerase II. Genes $\&$ Dev. 10: 2657-2683.

Otwinowski, Z., R. Schevitz, R.-G. Zhang, C. Lawson, A. Joachimiak, R. Marmorstein, B. Luisi, and P. Sigler. 1988. Crystal structure of trp repressor/operator complex at atomic resolution. Nature 335: 321-329.

Pabo, C. and R. Sauer. 1992. Transcription factors: Structural families and principles of DN A recognition. Annu. Rev. Biochem. 61: 1053-1095.

Parkinson, G., C. Wilson, A. Gunasekera, Y. Ebright, R. Ebright, and H. Berman. 1996. Structure of the CAP-DN A complex at 2.5 resolution: A complete picture of the protein-DNA interface. J. Mol. Biol. 260: 395-408.

Peterson, M., J. Inostroza, M. Maxon, O. Flores, A. Admon, D. Reinberg, and R. Tjian. 1991. Structure and functional properties of human general transcription factor IIE. Nature 354: 369-373.

Roberts, S., B. Choy, S. Walker, Y.-S. Lin, and M. Green. 1995. A role for activator-mediated TFIIB recruitment in diverse aspects of transcriptional regulation. Curr. Biol. 5: 508-516.

Roeder, R. 1996. The role of general initiation factors in tran- scription by RNA polymerase II. Trends Biochem. Sci. 21: 327-335.

Sawadogo, M. and R. Roeder. 1985. Interaction of a gene-specific transcription factor with the adenovirus major late promoter upstream of the TATA box region. Cell 43: 165-175.

Shen, W. and M. Green. 1997. Yeast TAFII145 functions as a core promoter selectivity factor, not a general coactivator. Cell 90: 615-624.

Tang, H., X. Sun, D. Reinberg, and R. Ebright. 1996. Proteinprotein interactions in eukaryotic transcription initiation: Structure of the pre-initiation complex. Proc. Natl. Acad. Sci. 93: 1119-1124.

Thiesen, H.-J. and C. Bach. 1990. Target Detection Assay (TDA): A versatile procedure to determine DNA binding sites as demonstrated on SP1 protein. Nucleic Acids Res. 18: 32033209.

Wang, B.Q., C. Kostrun, A. Finkelstein, and Z. Burton. 1993. Production of human RAP30 and RAP74 in bacterial cells. Protein Express. Purif. 4: 207-214.

Weis, L. and D. Reinberg. 1997. Accurate positioning of RNA polymerase II on a natural TATA-less promoter is independent of TATA-binding-protein-associated factors and initiator-binding proteins. Mol. Cell. Biol. 17: 2973-2984.

Xu, L., M. Thali, and W. Schaffner. 1991. Upstream box/TATA box order is the major determinant of the direction of transcription. Nucleic Acids Res. 19: 6699-6704. 


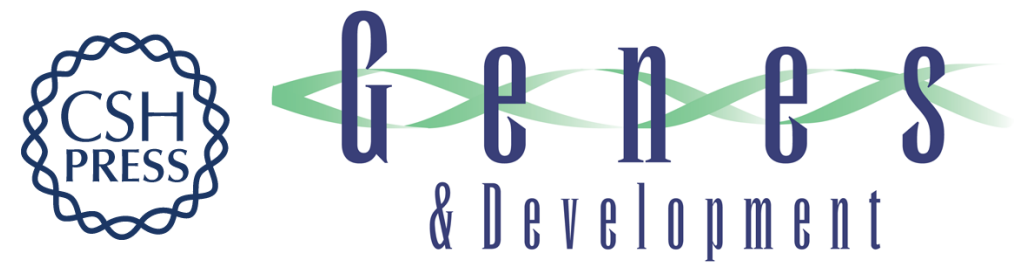

\section{New core promoter element in RNA polymerase II-dependent transcription: sequence-specific DNA binding by transcription factor IIB}

Thierry Lagrange, Achillefs N. Kapanidis, Hong Tang, et al.

Genes Dev. 1998, 12:

Access the most recent version at doi:10.1101/gad.12.1.34

References This article cites 42 articles, 17 of which can be accessed free at:

http://genesdev.cshlp.org/content/12/1/34.full.html\#ref-list-1

License

Email Alerting Receive free email alerts when new articles cite this article - sign up in the box at the top Service right corner of the article or click here.

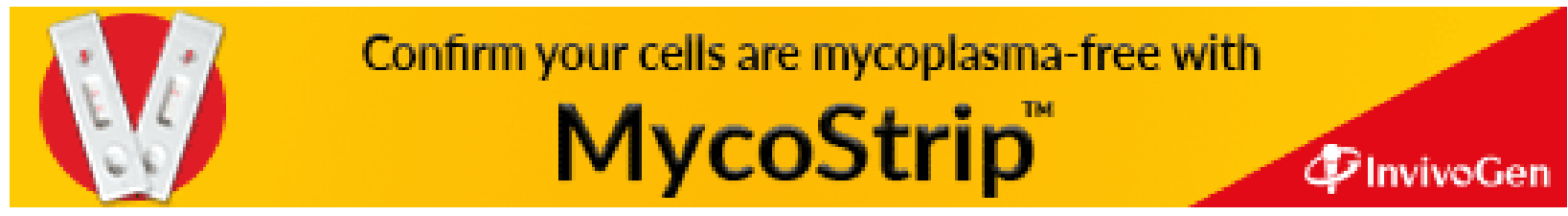

